\title{
MUSHROOM VALUE CHAIN AND ROLE OF VALUE ADDITION
}

\author{
AFIFA JAHAN ${ }^{1} \&$ BHOOPENDRA KUMAR SINGH ${ }^{2}$ \\ ${ }^{1}$ Scientist, Krishivigyan Kendra, Palem, Nagarkurnool District, Telangana, India \\ ${ }^{2}$ Senior Scientist \& Head, YFA-Krishi Vigyan Kendra, Wanapathy District, Telangana, India
}

\begin{abstract}
Mushrooms are nutritious, medicinal and functional food. It contains low calories, high protein, dietary fiber, vitamins, and minerals. It is very promising in its agribusiness trend, but has a constraint low shelf life. Mushroom value chain is classified into input suppliers, producers, traders, processors and consumers. Spawn suppliers played the major role in the distribution of inputs, collection and marketing of the produce. The produce has to be modified to more durable products, thus adding value to mushroom. Women empowerment and lack of time for cooking also increased demand for convenient products of mushrooms. In India value addition of mushroom represents approximately $7 \%$ which is lower than some developing countries. Hence there is a need to improve the value chain system and increase value addition. Many novel value-added products can be prepared with mushrooms like soup powder, pickles, chips, paste, ketchup, noodles, pasta, biscuits, nuggets.
\end{abstract}

Received: Dec 28, 2018; Accepted: Jan 18, 2019; Published: Feb 01, 2019; Paper Id.: IJBRJUN20192

\section{INTRODUCTION}

Mushrooms are an edible fungus typically grown above the soil. Mushrooms grow at temperatures ranging $15-23^{0} \mathrm{c}$. There are different types of mushrooms like milky mushrooms, White button mushroom, Crimino Mushroom, Portabello Mushroom, Shiitake Mushroom, Maitake Mushroom, Oyster Mushroom, Enoki Mushroom, Beech Mushroom, Black Trumpet Mushroom, King Trumpet Mushroom, Chanterelle Mushroom, Hedgehog Mushroom, Morel Mushroom, Porcino Mushroom. The three majorly grown mushrooms in India are button mushrooms, milky mushrooms, oyster mushrooms.

Mushrooms are nutritious, medicinal and functional food. It is considered as a health food as it contains low calories, high protein, dietary fiber, vitamins, and minerals (Barros et al., 2008). Mushrooms are nutritionally desirable because of their low energy value, fiber content, and high antioxidant capacity (Kalac, 2013). According to reports of Cheung 2010 different species of mushroom contains different amount of carbohydrates which usually ranges between $35-70 \%$, including digestible and non-digestible carbohydrates. The protein content ranges from 1.6 -2.1 g/100g (Mattila et al., 2002). According to Sadler (2003), mushrooms are a good source of insoluble fiber in the form of chitin (polymer of $\mathrm{N}$-acetyl-glucosamine) and non-starch polysaccharides like $\beta$-glucans. Mainly mushrooms are low in fat and a good source of unsaturated fatty acids, $75 \%(\mathrm{w} / \mathrm{w})$ of the total fatty acidsas per reports of Andre et al. (2010). Mushrooms are a good source of vitamins and minerals, particularly thiamine, riboflavin, niacin, biotin, pantothenic acid, Folic acid, vitamin B12, calcium, magnesium, sodium, potassium, phosphorus, copper, iron, manganese and zinc (Cheung, 2008 and Bhal, 1989). Therefore, mushrooms are considered as an excellent food source to alleviate malnutrition in developing countries (Pathmashini, 2008). 
Mushrooms have medicinal values due to presence of Host Defense Potentiators (HDP) which enhance immune system and has properties like antibacterial activities, antitumor, antihypertensive and hypocholesterolemic, antimicrobial and anti-HIV effects, anti-inflammatory, and immune stimulatory activities antitumorogenic effects (Israilides et al., 2008; Wasser,2010; Rahman and Choudhury, 2012; Tang et al., 2006; Ramberg et al., 2010; Alam et al. 2011 and Patel et al., 2012).

The functional food ingredients in the mushrooms are dietary fiber, poly-unsaturated fatty acids (PUFA), proteins, peptides, amino acids, keto acids, minerals, vitamins and other antioxidants (glutathione, selenium, etc.) The presence of bioactive compounds like $\beta$-glucans classified mushrooms as functional foods due to its properties like antibacterial, antihypertensive, antihyperholesterolemia, detoxification, hepatoprotective, and antidiabetic activities antidiabetic properties antiparasitic, antitumor, antiviral and also have an ability to maintain the blood cholesterol at the optimum level preventing cardiovascular diseases (Chioza, 2014; Wasser and Weis, 1999; Wasser, 2002; Sadler, 2003; Lindequist et al., 2005). Due to their immunomodulatory properties, purified $\beta$-glucans have been used clinically as part of a combination therapy for a variety of cancers (Thompson et al., 2010).

\section{MUSHROOMS VALUE CHAIN}

Major mushroom producing countries are China, USA and Netherlands, and they share 47, 11, and 7\% of world supply, respectively. The remaining 35\% of the total production was from Italy, France, Poland, Ireland, United Kingdom, Canada and India (Harsh and Joshi, 2008). Sharma et al. (2017) reported that the total production of mushrooms in India is 0.13 million tons (approx.) and in total production of mushroom white button shown is $73 \%$, oyster mushroom hold $16 \%$ paddy straw mushroom $7 \%$ and milky mushroom 3\%. It was also reported that Indian mushroom industry revenue generation for the year 2016-17 was Rs7282.26 lacs. by exporting 1054 quintals of white button mushroom in canned.

The market value of dietary supplements made from mushrooms is quickly growing and estimated over U.S. $\$ 15$ billion (Wasser, 2012). Mushroom value chain is classified into input suppliers, producers, traders, processors and consumers. Production of mushroom in India is based on season and as well as high tech system industry. Favourable natural agro-climate conditions of India combination with availability of agro-wastes which favors diversified mushroom species cultivation (Manjit Singh and Shwet Kamal, 2012).

According to Dhar and Sharma (2009), Pleurotusostreatus (oyster mushroom)mushroom cultivation is very popular and next to Agaricusbisporus (common white mushroom/ button mushroom) mushroom in India in reference to consumer acceptance. In India, thesetwospices are major contributor in edible mushrooms production (about 100000 tons per annum, 2008-09). Farmers interested in additional income the small scale mushroom production is an opportunity specifically for small, marginal or landless farmers (Ranathunge, 2010). Mushroom business is well suited for both females and males of all levels of education and the role of women in the production and trade of mushroom were higher than that of men (Birhanu and Zerihun, 2012).

Spawn suppliers played the major role in the distribution of inputs, collection and marketing of the product (Woldemedhin, 2016). In India the spawn demand is estimated about 8000-10000 tons per annum (Sharma et al., 2017).

Industrialization and rise of supermarkets in developing countries have undergone major changes in world's food distribution system with multilateral, regional and bilateral free trade agreements that include agricultural products and the emergence of global food supply chains (Berdegué et al. 2005, Hernandez et al., 2007). Hence, these development are 
leading to major re-governing of the market linkages between farmers and other stakeholders in agro-industries (Vorley et al. 2007). To improve developmental research is carried out in supply chain work to understand stakeholders and chain leaders (Poole et al., 2003; Chen et al., 2005; Moustier et al., 2006; Batt and Cadilhon, 2007; Vorley et al., 2007). To support this, government and development agencies are actively supporting farmers to gain access in income generating markets (Ferrand et al., 2004;Bernet et al., 2006 and KIT et al., 2006).

Shepherd (2007), reported many of the linkages created by development practitioners are not sustainable because some small farmers are unable to adhere their quality standards of demanding markets. However, the private sector is recognized as being a major driver for sustainable market linkages for small producers (Caniels et al., 2006; Batt and Cadilhon 2007; Shepherd, 2007 and Vorley et al., 2007).

Mushrooms are traded world wide in the processed forms like frozen, canned, pickled, dried, etc. which increases shelf-life and market value (Manzi et al., 2001). Many novel value-added products can be prepared with mushrooms like soup powder, pickles, chips, paste, ketchup, noodles, pasta, biscuits, nuggets, mushroom-based flavour enhancers, as an additive in beverages and beauty products (Zivanovic, 2006; Rai and Arumuganathan, 2008). It's the need of the hour not only to reduce the losses, but also to enhance the income by value-addition and boost the mushroom consumption (Mehta et al., 2011). In India the per capita consumption of mushroom is a dismal $30-40 \mathrm{~g}$ as compared to $2-3 \mathrm{~kg}$ in American and European countries. India is a big market and increase of per capita consumption even up to $100 \mathrm{~g}$ will help growers to market over 1.00 lakh ton mushrooms within the country (Manjit Singh and Shwet Kamal 2012).

Mushroom market is unstructured, as it is sold in most of the local market without standard packaging \& measurement, unspecified quantities, qualities and the pricevariation. Many times getting the product in the market is a matter of chance; the customers have little or no knowledge as to where to get the product especially when the production season is completed.

The Marketing is not well defined as most of the time the small and marginal farmers are those who cultivate the mushroom and thus get to the final consumer without letting the produce pass through other agents like wholesalers, retailers and processor. This poses the problem of insufficient added value to the mushroom sold and lesser job opportunities.

According to the reports of Vidya(2001), there are various marketing channels followed by the mushroom producers in Indian scenario especially in H.P and U.Plike states1. Producer-Retailer-Consumer 2. Producer-Consumer 3. Producer-Co-operative-Retailer-Consumer. In addition to these three channels, in states like Bihar growers are using two more channels like Producer - NGO - Retailer - Consumers and Producer - Outside collector - Wholesaler - Retailer Consumer.

Mushrooms are highly perishable. Hence the marketing channels should be as short and fast as possible. Costing of mushrooms should be done very carefully keeping in view the expenses of cultivation, packing, transportation and other expenses of labouretc. $49 \%$ of the mushroom farmers were found to be inefficient in the knowledge and techniques of mushroom cultivation. The other problems faced by mushroom farmers in Indian scenario are lack of capital, lack of labour, lack of credit, unavailability of inputs and other miscellaneous problems like electricity etc. (Vidya, 2011). 


\section{MUSHROOM PROCESSING AND VALUE ADDITION}

Mainly mushrooms are used in the fresh conditions. It is very promising in its agribusiness trend, but has a constraintof low shelf life. To overcome this constraint, the product has to be processed to more durable products thus adding value to mushrooms. The demand for individual portion packs and convenience formats in every day diet due to women empowerment and lack of time.Hence, the demand ofconvenient product of mushroom in increased (BordGlas, 2002).

Mushrooms are worldwide trade in the processed forms like frozen, canned, pickled, dried etc. which increases shelf-life and value of the product (Manzi et al., 2001). In India value addition of mushroom represents approximately 7\% (which is lower than some developing countries) and mushroom products are available as bakery products (biscuits, bread, cakes), and fast food items like burgers, cutlets and pizza etc. (Harsh and Joshi, 2008).

Mushroom is sliced and dried, it can be made into powders to be used as additive to increase content of dietary fibers in various foods and as a partial substitute for wheat flour in the bakery products or the dried slices are used directly in soups biscuits, nuggets and snacks preparation (Zivanovic, 2006). Other mushroom-based food products like bread, cake, roasted mushrooms in oil, mushroom pate, etc. have been prepared to add value to mushrooms and increase the consumption of mushrooms by children and elderly people (Zivanovic, 2006; Ravi and Siddiq, 2011).

Beverages and Beauty Products Flavour and bioactive compounds can be extracted with water or alcohol and the extracts can be used for preparation of mushroom beers, wines, spirits, and prophylactic drinks (Zivanovic, 2006).

The shelf life of mushrooms can be increased by refrigerating at $22^{\circ} \mathrm{c}$ for at least $1-3$ days (Burton and Twyning, 1989), at $15^{\circ} \mathrm{C}$ it can be increased to $2-3$ days (Gormley, 1981). The most common method of mushroom preservation by the cryogenic method is blast freezing (Jaworska and Bernas, 2009). Blast freezers rapidly bring the temperature of foods down, freezing them extremely quickly from $-25^{\circ} \mathrm{C}$ to $-30^{\circ} \mathrm{C}$, creating small ice crystals that damage less the mushroom cells. Freon, plate, and individual quick freezing are some of the methods used in mushrooms storage (Coggins and Chamul, 2004).

According to Brennan and Gormley(1998), the practice of washing or dipping whole mushrooms in treatment solutions prior to slicing is more effective, in terms of shelf-life, than dipping, spraying, or brushing solutions onto sliced mushrooms. After washing and prior to freezing and canning, with the use of hot water or steam blanching is also practices as an important treatment applied during preliminary processing of mushrooms. This process inhibits tissue browning (inactivation of polyphenol oxidase) and production of off flavours during mushroom frozen storage and defrosting. It also removes trapped air and decreases weight losses during canningmaking additionally the product more pliable to facilitate the filling operation (Wu et al., 1981).

Canning is another method of mushroom preservation which can increase the storage period up to 2 years with storage costs being relatively low. Even though usage of this process has dropped over the last years, about $38 \%$ of them are canned these days, holding a major share in world trade (Ravi and Siddiq, 2011). According to Czapski(2003), Desalted mushrooms can be also used in canning in air-tight containers. Mushrooms should be processed soon after harvest or should be stored at $4^{\circ} \mathrm{C}-5^{\circ} \mathrm{C}$ until processed. Beelman et al. (1973), has suggested storage at low temperature 1 day before canning.

The oldest and yet one of the most important preservation methods is drying/Dehydration. Methods for drying 
mushrooms include the conventional hot air drying, thin layer drying, vacuum drying, freeze-drying, microwave drying, and the more recently introduced fluidized bed and microwave-vacuum drying. The water activity of a product is reduced at a specific level (normally less than $10 \%$ ) so that it is microbiologically and physicochemically stable (Krokida et al., 2003). In this process the textural characteristics (hardness/firmness, cohesiveness, springiness, and chewiness) of mushrooms usually change (Kotwaliwale et al., 2007). Krokida et al. (1998) described the characterized dried products affected by temperature and duration of drying are colour, texture, density, porosity, and sorption. These dried products have an unlimited shelf - life, practically this is more than a year, due to significant quality deterioration (Jaworska et al., 2014). The great advantage of this method is the lower cost in transportation, handling, and storage compared to other preservation methods.

Mau and Huang (1997), reported that preservation by radiation i-e using gamma or x-rays at the dose of 100-150Krad has been found to restrict the postharvest growth and discoloration/deterioration of mushrooms, yet decrease with increase the level of irradiation dose the level of octo-carbon aromatic compounds (1-octen-3-ol, 3-octanone, etc.) present in the mushrooms. Combination of gamma radiation $(1.0 \mathrm{kGy})$ and passive MAP extended the shelf-life of Lentinula up to 20 days (Jiang et al. 2010). Its use is limited by the cost and the perception of consumers to irradiation on food (Przybylowicz and Donoghue, 1988). MAP is the simplest, most economical, and effective method for limiting tissue respiration rate, reducing microbial growth, and extending the shelf-life of mushrooms according to the reports of Kim et al. (2006).

Fresh mushrooms are packed in many ways depending on wholesale, retail, and transport requirements and their species characteristics. They are sold as either loose or in trays/punnets overwrapped with plastic films, usually PE and PVC of different permeability and stored under refrigeration temperature. To prevent the bacterial growth and colour change created by the moisture and modified atmosphere packaging (Burton et al., 1987), film perforation is suggested by Falguera et al. (2011) along with the use of new technology films with chosen permeability.

Roy et al. (1996), reported the two main problems related with mushroom packaging are the creation of an in-package anaerobic atmosphere, particular if non perforated films are used or in MAP and the water condensation development.

Gormley and MacCanna (1967), explained that over perforation may result in excessive mushroom water loss causing wrinkling and development of brown patches on the mushroom surfaces. Mahajan et al. 2008, has suggested the optimum humidity level for mushroom packaging to be $96 \%$ and for colour $87 \%-90 \%$ (Roy et al., 1996; Wakchaure, 2011). Barron et al.,(2002), has suggested a more practical way to control in-package humidity by the use of films with suitable moisture permeability.

According to the reports of Wakchaure (2011), montmorillonite clay and silica gel can be used to extend the shelf-life of a mushroom in packs. The overall impression of quality depends on Design, colour, and labeling (Burton et al., 1987). 


\section{CONCLUSIONS}

Mushrooms are easily grown and is a good enterprise for unemployed rural youths \& farmers. The skill in mushroom cultivation is important to acquire before starting mushroom production. As Sprawn supplier plays a major role in the distribution of inputs, collection and marketing of the produce, its market is unstructured. Mushrooms are sold in most of the local market without standard packaging \& measurement, unspecified quantities, qualities and the price variation. Hence there is a need to improve the value chain system and increase value addition. Awareness about various uses and value added products need to be given for increasing the production and consumption of mushrooms as it is nutritious, medicinal and functional food.

\section{REFERENCES}

1. Alam N., Amin R, Khan A., Ara I., Shim M., Lee M., Lee U., Lee T. 2009. Comparative effects of oyster mushrooms on lipid profile, liver and kidney function in hypercholesterolemic rats. Mycobiology 37(1): 37-42.

2. Alam N., Yoon K., Lee T., Lee U. 2011. Hypolipidemic activities of dietary Pleurotusostreatus in hypercholesterolemic rats. Mycobiology 39(1): 45-51.

3. Andlauer W. and Fürst P. 2002. Nutraceuticals: A Piece of History, Present Status and Outlook. Food Research International, 35, 171-176.

4. Andre A., Diamantopoulou P., Philippoussis A., Sarris D., Komaitis M., Papanikolaou S. 2010. Biotechnological conversions of bio-diesel derived waste glycerol into added-value compounds by higher fungi: Production of biomass, single cell oil and oxalic acid. Ind Crop Prod 31: 407-416.

5. Bahl, N. 1998. Hand Book on Mushrooms. Oxford \& I.B.H. Publishing Co. Pvt. Ltd., 15-40.

6. Barron C., Varoquaux P., Guilbert S., Gontard N., Gouble B. 2002. Modified atmosphere packaging of cultivated mushroom (Agaricusbisporus L.) with hydrophilic films. J Food Sci 67: 251-255

7. Barros L., Cruz T., Baptista P., Estevinho LM, Ferreira ICFR. 2008. Wild and commercial mushrooms as source of nutrients and nutraceuticals. Food ChemToxicol 46: 2742-2747.

8. Batt, Peter J. and Jean-Joseph Cadilhon (eds) (2007) Proceedings of the international symposium on fresh produce supply chain management. 6 to 10 December 2006 Lotus Pang SuanKaeo Hotel, Chiang Mai, Thailand, Bangkok: AFMA, Curtin University of Technology (Perth, WA), Thai Department of Agriculture and FAO.

9. Beelman RB, Kuhn GD, McArdle FJ. 1973. Influence of post-harvest storage and soaking on the yield and quality of canned mushrooms. J Food Sci38(6): 951-953.

10. Berdegué, Julio A., Fernando Balsevich, Luis Flores and Thomas Reardon (2005) 'Central American supermarkets' private standards of quality and safety in procurement of fresh fruits and vegetables', Food Policy 30(3):254-269.

11. Bernet, Thomas, Graham Thiele and Thomas Zschocke (eds) (2006) Participatory Market Chain Approach (PMCA): User Guide, Lima: International Potato Centre and Papa Andina.

12. Bobek, P. and Galbary, S. 2001. Effect of Pleuran( $\beta$-Glucan from Pleurotus o streatus) on the Antioxidant Status of the Organism and on Dimethylhydrazine-Induced Precancerous Lesions in Rat Colon. British Journal of Biomedical Science, 58, 164-168.

13. BordGlas. 2002. In: The Horticultural Development Board (ed.). Mushrooms. Dublin, Ireland: BordGlas. 25pp.

14. Brennan MH, Gormley TR. 1998. Extending the Shelf Life of Fresh Sliced Mushrooms. Dublin, Ireland: Teagasc. p. 21. 
15. Burton KS, Frost CE, R. Nichols. 1987. A combination plastic film system for controlling post harvest mushroom quality. BiotechnolLett 9(8): 529-534.

16. Burton KS, Twyning RV. 1989. Extending mushroom storage life by combining modified atmosphere packaging and cooling. ActaHortic 258: 565-571

17. Caniëls, Marjolein C.J., Henny A. Romijn and Marieke de Ruijter-De Wildt (2006) 'Can business development services practitioners learn from theories on innovation and services marketing?', Development in Practice 16(5):425-440.

18. Chen, Kevin, Andrew W. Shepherd and Carlos Da Silva (2005) Changes in food retailing in Asia - Implications of supermarket procurement practices for farmers and traditional marketing systems, Agricultural Management, Marketing and Finance Occasional Paper No. 8, Rome: FAO

19. Cheung P C. 2008. Nutritional value and health benefits of mushrooms. In: Cheung PC (ed.). Mushrooms as Functional Food. Hoboken, NJ: John Wiley \& Sons, Inc. pp. 71-109.

20. Cheung P C. 2010. The nutritional and health benefits of mushrooms. Nutr Bull 35: 292-299.

21. Chioza, A. and Ohga, S. 2014. Cultivated Mushrooms in Malawi: A Look at the Present Situation. Advances in Microbiology, 4, 6-11.

22. Coggins PC, Chamul RS. 2004. Food sensory attributes. In: Hui YH, Cornillon P, Legaretta IG, Lim MH, Murrell KD, Nip WK (eds.). Handbook of Frozen Foods. New York: Marcel Dekker Inc. pp. 93-148.

23. Czapski J. 2003. Evaluation of chemical composition of commercially canned mushrooms processed from fresh and desalted mushrooms and derived from different geographic regions. Veg Crops Res Bull 58: 135-141.

24. Dhar, B.L., Sharma, S.K. (2009). Medical Mushroom product in India, present status and future trading. Proc. 5th Int. Medicinal Mushroom Conference, Mycological Society of China, Nantong, China, pp. 403-406.

25. Falguera V, Quintero JP, Jiménez A, Muñoz JA, Ibarz A. 2011. Edible films and coatings: Structures, active functions and trends in their use. Trends Food SciTechnol 22(6): 292-303.

26. Ferrand, David, Alan Gibson and Hugh Scott (2004) "Making markets work for the poor". An objective and an approach for governments and development agencies, Woodmead, South Africa: The ComMark Trust.

27. Getachew, D. Woldemedhin1*, Zemedu, L. Seifu2 and Eshete, A. Wassie3. 2016. Mushroom value chain analysis in Addis Ababa, Ethiopia..Vol.8(8), pp. 130-140, August 2016. Journal of Agricultural Extension and Rural Development.

28. Gormley TR, Mac Canna C. 1967. Prepackaging and shelf-life of mushrooms. Irish J Agric Res 6(2): 255-265.

29. Gormley TR. 1981. Aroma in fruit and vegetables. In: Goodenough PW, Atkin RK (eds.). Quality in Stored and Processed Vegetables and Fruit. New York: Academic Press. pp. 47-48.

30. Harsh NSK and Joshi K.2008. Mushrooms: The vegetable of the future. Science and Technology for rural India and inclusive growth: Science and Technology, India.

31. Hernández, Ricardo, Thomas Reardon and Julio A. Berdegué (2007) 'Supermarkets, wholesalers, and tomato growers in Guatemala', Agricultural Economics 36:281-290.

32. Hossain, S., Hashimoto, M., Choudhury, E.K., Alam, N., Hussain, S., Hasan, M., Choudhury, S.K. and Mahmud, I. (2003) Dietary Mushroom ( Pleurotusostreatus) Ameliorates Atherogenic Lipid in Hypercholesterolaemic Rats. Clinical and Experimental Pharmacology and Physiology, 30, 470-475. 
33. Israilides C, Kletsas D, Arapoglou D, Philippoussis A, Pratsinis H, Ebringerova A, Hribalova V, Harding SE. 2008. In vitro cytostatic and immunomodulatory properties of the medicinal mushroom Lentinulaedodes. Phytomedicine 15(6-7): 512-519.

34. Jaworska G, Bernaś E. 2009. The effect of preliminary processing and period of storage on the quality of frozen Boletus edulis (Bull: Fr.) mushrooms. Food Chem 113: 936-943.

35. Jaworska G, Pogoń K, Bernaś E, Skrzypczak A. 2014. Effect of different drying methods and 24-month storage on water activity, rehydration capacity, and antioxidants in Boletus edulis mushrooms. Dry Technol 32: 291-300.

36. Jiang T, Shasha L, Chen Q, Shen LX, Ying T. 2010. Effect of integrated application of gamma irradiation and modified atmosphere packaging on physicochemical and microbiological properties of shiitake mushroom (Lentinusedodes). Food Chem 122: 761-767.

37. Kalac P. 2013. A review of chemical composition and nutritional value of wild-growing and cultivated mushrooms. J Sci Food Agric 93(2): 209-218.

38. Kim KM, Ko JA, Lee JS, Park HJ, Hanna MA. 2006. Effect of modified atmosphere packaging on the shelf life of coated, whole and sliced mushrooms. LWT_Food SciTechnol 39: 364-371.

39. KIT, Faida Ma Li and IIRR (2006) Chain Empowerment: Supporting African Farmers to Develop Markets, Amsterdam: Royal Tropical Institute.

40. Kotwaliwale N, Bakane P, Verma A. 2007. Changes in textural and optical properties of oyster mushroom during hot air drying. J Food Eng 78: 1207-1211.

41. Krokida MK, Karathanos VT, Maroulis ZB, Marinos-Kouris D. 2003. Drying kinetics of some vegetables. J Food Eng 59: 391-403.

42. Krokida MK, Tsami E, Maroulis ZB. 1998, Kinetics on colour changes during drying of some fruits and vegetables. Dry Technol 16: 667-685.

43. Kruger, C.L. and Mann Safety, S.W. 2003. Safety Evaluation of Functional Ingredients. Food and Chemical Toxicology, 41, 793-805.

44. Lindequist U, Niedermeyer TH, Julich WD. 2005. The pharmacological potential of mushrooms. Evid Based Complement Alternat Med 2: 285-299.

45. Mahajan PV, Rodrigues FAS, Motel A, Leonhard A. 2008b. Development of moisture absorber for packaging of fresh mushrooms (Agaricusbisporus). Postharvest BiolTechnol 48: 408-414.

46. Manjit Singh and Shwet Kamal 2012. Mushroom Scenario in Indi. Agriculture Year Book 2012. Pg. no. 83-87.

47. Manzi P, Aguzzi A, Pizzoferrato L. 2001. Nutritional value of mushrooms widely consumed in Italy. Food Chem 73(3): 321325.

48. Mattila P, Salo-Vaananen P, Konko K, Aro H, Jalava T. 2002. Basic composition and amino acid contents of mushrooms cultivated in Finland. J Agric Food Chem 50: 6419-6422.

49. Mau JK and Huang Sh-J. 1997. Effect of $\gamma$-radiation on flavour compounds of fresh mushrooms. J Food Chem 45: 255-260.

50. Mehta B. K, Jain SK, Sharma G. P., Doshi A and Jain H. K. 2011. Cultivation of button mushroom and its processing: A techno-economic feasibility. Int J Adv Biotechnol Res 2: 201-207.

51. Patel S and Goyal A. 2012. Recent developments in mushrooms as anticancer therapeutics: A review. 3. Biotechnology 2: 115. 
52. Pathmashini, L., Arulnandhy, V. and Wijeratnam, R.S.W. 2008. Cultivation of Oyster Mushroom ( Pleurotusostreatus ) on Sawdust. Ceylon Journal of Science (Biological Sciences ), 37, 177-182.

53. Poole, Nigel D., A. WayoSeini and Victor Heh (2003) 'Improving agri-food marketing in developing economies: contractual vegetable markets in Ghana', Development in Practice 13(5):551-557.

54. Salu, A., \& BK, Y. (2016). Effect of Temperature and Ozone Treatment on The Respiration of Oyster Mushroom.

55. Przybylowicz P and Donoghue J. 1988. Marketing, harvesting, and processing shiitake. In: Shiitake Growers Handbook: The Art and Science of Mushroom Cultivation. Dubuque, IA: Kendall/Hunt Publishing Co. pp. 169-188.

56. Rahman T and Choudhury M. B. K. 2012. Shiitake mushroom: A tool of medicine. Bangladesh J Med Biochem 5(1): 24-32.

57. Rai R. D. and Arumuganathan T. 2008. Post harvest technology of mushrooms. Report of Technical Bulletin. New Delhi, India: National Research Centre for Mushroom.

58. Ramberg JE, Nelson ED, Sinnott RA. 2010. Immunomodulatory dietary polysaccharides: A systematic review of the literature. Nutr J 9: 1-22.

59. Ranathunge, P.R.M.P.D., Rankothge, C. and Wickremasinghe, S.L. 2010. Small and Medium Mushroom Enterp in Sri Lanka: A Case Study on the Innovation System involved, National Science Foundation (NSF), Sri Lanka.

60. Ravi R and Siddiq M. 2011. Edible mushrooms: Production, processing and quality. In: Sinha NK, Hui YH, Evranuz EÖ, Siddiq M, Ahmed J (eds.). Handbook of Vegetables and Vegetable Processing. Ames, IA: Wiley-Blackwell. pp. 643-661.

61. Ravi R. and Siddiq M. 2011. Edible mushrooms: Production, processing and quality. In: Sinha NK, Hui YH, Evranuz EÖ, Siddiq M, Ahmed J (eds.). Handbook of Vegetables and Vegetable Processing. Ames, IA: Wiley-Blackwell. pp. 643-661.

62. Roy S, Anantheswaran RC, Beelman RB. 1996. Modified atmosphere and modified humidity packaging of fresh mushrooms. $J$ Food Sci 61: 391-397.

63. Sadler M. 2003. Nutritional properties of edible fungi. Nutr Bull 28(3): 305-308.

64. Sadler M. 2003. Nutritional properties of edible fungi. Nutr Bull 28(3): 305-308.

65. Sharma V. P., Sudheer K Annepu, Yogesh Gautam, Manjit Singh and Shwet Kama. 2017. Status of mushroom production in India. Mushroom Research. 26 (2): 111-120, 2017

66. Shepherd, Andrew W. 2007. Approaches to linking producers to markets - A review of experiences to date, Agricultural Management, Marketing and Finance Occasional Paper No. 13, Rome: FAO.

67. Tang W, Liu JW, Zhao WM, Wei DZ, Zhong JJ. 2006. Ganoderic acid T from Ganodermalucidum mycelia induces mitochondria mediated apoptosis in lung cancer cells. Life Sci 80(3): 205-211.

68. Thompson I, Oyston P, Williamson D. 2010. Potential of the $\beta$-glucans to enhance innate resistance to biological agents. Expert Rev 8(3): 339-352.

69. VaidyaC.S. 2001. Problems, potential and economics of mushroom cultivation - a study in Himachal Pradesh, Uttar Pradesh and Bihar, Agro-economic research centre Himachal Pradesh University, Shimla.

70. Vasudewa, N.S., Abeytunga, D.T.U. and Ratnasooriya, W.D. (2007) Antinociceptive Activity of Pleurotusostreatus, an Edible Mushroom, in Rats. Pharmaceutical Biology, 45, 533-540.

71. Vorley, Bill, Andrew P. Fearne and Derek Ray (eds) (2007) Regoverning markets. A place for small-scale producers in modern agrifood chains, Aldershot, UK, and Burlington, VT: Gower. 
72. Wakchaure G. C. 2011. Postharvest handling of fresh mushrooms. In: Singh M, Vijay B, Kamal S, Wakchaure GC (eds.). Mushrooms: Cultivation, Marketing and Consumption. Solan, India: Directorate of Mushroom Research, Indian Council of Agricultural Research (ICAR). pp. 197-206.

73. Shinde, S. D., \& Gaikwad, V. Application Of Gis For Mapping Rainwater Harvesting Potential: A Case Study Of Nidhal Village In Satara District, Maharashtra, India.

74. Wasser S. P. 2002. Medicinal mushroom as a source of antitumor and immunomodulating polysaccharides. Appl Microbiol Biotechnol 60: 258-274.

75. Wasser S. P. and Weis AL. 1999. Medicinal properties of substances occurring in higher basidiomycetes mushrooms: Current perspectives. Int J Med Mushroom 1: 31-62.

76. Wasser SP. 2010a. Shiitake (Lentinusedodes). In: Coates PM, Betz, GM, Blackman MR, Cragg GM, Levine M, Moss J, White JD (eds.). Encyclopedia of Dietary Supplements, 2nd edn. New York: Informa Healthcare. pp. 719-726.

77. Wu CM, Wu JLP, Chen CC, Chou CC. 1981. Flavor recovery from mushroom blanching water. In: Charalambous G, Inglett G (eds.). The Quality of Foods and Beverages: Chemistry and Technology, Vol. 1. New York: Academic Press. pp. 133-145.

78. Zivanovic S. 2006. Identification of opportunities for production of ingredients based on further processed fresh mushrooms, off-grade mushrooms, bi-products, and waste material. Knoxville, TN: Mushroom Council, University of Tennessee, Department of Food Science and Technology. p. 33. 